\title{
Zawartość pyłów w gazie jako istotny element oceny jakości gazu
}

\begin{abstract}
W artykule przeanalizowano obowiązujące regulacje prawne i wymagania techniczne w zakresie oznaczania zawartości pyłów w gazach, ze szczególnym zwróceniem uwagi na gazy palne wykorzystywane w energetyce oraz transporcie samochodowym, jak również na gazy techniczne zasilające aparaturę kontrolno-pomiarową i analityczną.
\end{abstract}

Słowa kluczowe: jakość gazu, zawartość pyłu, pył.

\section{Dust content in gas as an important element of gas quality assessment}

This article analyzes the applicable legal regulations and technical requirements for the determination of dust content in gases, with particular attention to flammable gases for use in power generation and road transport, as well as for industrial gases for control and measurement equipment.

Key words: gas quality, dust content, dust.

\section{Wstęp}

Analiza jakości gazów palnych koncentruje się w główniej mierze na wyznaczeniu ich parametrów energetycznych, zawartości związków siarki lub wody [2, 7-10]. O wiele rzadziej w tym kontekście poruszane są zagadnienia związane z zawartością pyłów w paliwach gazowych. Niemniej jednak obecny w gazie pył jest istotnym zanieczyszczeniem, które może obniżać wartości użytkowe gazów palnych oraz technicznych. Zawarty w gazie pył może prowadzić do uszkodzenia zarówno aparatury kontrolno-pomiarowej, jak i urządzeń zasilanych gazem, a także negatywnie wpływać na zdrowie użytkowników tego paliwa. W związku z tym istotne jest prawidłowe prowa- dzenie kontroli jakości gazu, uwzględniające zawartość pyłu zarówno w przypadku paliw gazowych, jak i gazów technicznych wykorzystywanych w przemyśle. Mimo że zawartość pyłu w gazie może w znacznym stopniu wpływać niekorzystnie na właściwości użytkowe gazu, aspekt ten bardzo często jest pomijany w specyfikacjach prawnych i technicznych, przeznaczonych dla różnego typu paliw gazowych. Niniejszy artykuł stanowi przegląd wymagań prawnych i technicznych w zakresie oznaczania zawartości pyłów w paliwach gazowych i gazach technicznych oraz stanowi odpowiedź na pytanie, czy parametr ten powinien być limitowany i kontrolowany.

\section{Analiza wymagań prawnych i technicznych stawianych różnego typu paliwom gazowym}

Pył zawarty w gazach palnych lub technicznych może w negatywny sposób wpływać na pracę urządzeń wykorzystujących to medium, między innymi poprzez ścieranie zaworów i innych elementów ruchomych, zmniejszanie średnic czynnych instalacji rozprowadzających, a także zatykanie filtrów. Z tego względu zawartość pyłów w gazach powinna być limitowana. Najczęściej jednak limity te znajdują się jedynie w odpowiednich normach przedmiotowych, a nie bezpośrednio w aktach prawnych, co w znacznym stopniu ogranicza konieczność weryfikacji tego parametru.

Najczęściej wykorzystywanym paliwem gazowym rozprowadzanym sieciami gazowymi jest gaz ziemny. Jego jakość została określona w Rozporządzeniu Ministra Gospodarki z dnia 2 lipca 2010 r. w sprawie szczegółowych warunków 
funkcjonowania systemu gazowego [28]. W rozdziale 8 przedstawione zostały wymagania jakościowe stawiane gazom ziemnym transportowanym sieciami gazowymi. Parametry jakościowe limitowane według tego rozporządzenia to:

- zawartość związków siarki, w tym siarkowodoru i siarki merkaptanowej,

- zawartość par rtęci,

- temperatura punktu rosy wody,

- ciepło spalania i liczba Wobbego,

- stopień nawonienia gazu transportowanego siecią dystrybucyjną.

Wśród wymagań jakościowych zawartych w rozdziale 8 rozporządzenia [28] brak jest wymagań limitujących zawartość pyłów w gazie ziemnym. Taka sytuacja powoduje, że zgodnie z wymogami polskiego prawa ilość pyłów w gazie ziemnym nie jest limitowana oraz nie musi być kontrolowana. Niemniej jednak wymagania jakościowe dotyczące maksymalnej zawartości pyłów w gazie ziemnym można znaleźć w odpowiednich normach polskich i europejskich dotyczących jakości gazu. Seria polskich norm (od PN-C-04750 do PN-C-04753) dotyczy klasyfikacji, oceny jakości i wymagań jakościowych stawianych gazom ziemnym dystrybuowanym sieciami gazowymi. W normach PN-C-04752:2011 [14] i PN-C-04753:2011 [15] zebrane zostały wymagania jakościowe stawiane odpowiednio gazom ziemnym w sieci przesyłowej i dystrybucyjnej. Zakres wymagań jakościowych zawartych $\mathrm{w}$ tych normach jest znacznie większy niż w rozporządzeniu [28]. Wymagania jakościowe stawiane gazom ziemnym w normach $[14,15]$ uzupełniono o takie parametry jak:

- zawartość tlenu w gazie w obu rodzajach sieci oraz zawartość tlenku węgla(IV) w gazie w sieci przesyłowej,

- temperatura puntu rosy węglowodorów wraz z zawartością węglowodorów mogących ulec kondensacji w gazie dla sieci przesyłowej,

- wartość opałowa gazu w sieci dystrybucyjnej,

- zawartość pyłów w gazie w obu rodzajach sieci.

Limit dotyczący dopuszczalnej zawartości pyłów w gazie, zgodnie z normami PN-C-04752 [14] oraz PN-C-04753 [15], jest taki sam i wynosi $1 \mathrm{mg} / \mathrm{m}^{3}$ dla pyłu o średnicy cząstek powyżej $5 \mu \mathrm{m}$. Zgodnie z zapisami norm zawartość pyłów w gazie ziemnym powinna być kontrolowana $\mathrm{z}$ częstotliwością minimum 2 razy w roku $[14,15]$. Uwzględnienie parametru, jakim jest zawartość pyłów w gazie, w serii polskich norm wskazuje na fakt, że parametr ten jest istotny zarówno z punktu widzenia odbiorców gazu ziemnego, jak i operatorów sieci. Polskie normy nie są jednak jedynymi standardami technicznymi opublikowanymi w tym zakresie. Do jakości gazu ziemnego odnosi się wydana w 2015 r. norma europejska EN 16726 Infrastruktura gazowa - Jakość gazu - Grupa $H$ [25], której zapisy dążą do ułatwienia swo- bodnego przepływu gazu na wewnętrznym rynku Unii Europejskiej, w celu promowania konkurencyjności i bezpieczeństwa dostaw gazu. Zgodnie z zapisami tej normy zawartość pyłów w gazie nie jest limitowana w sposób bezpośredni. Jednak znajduje się w niej wymaganie dotyczące obecności zanieczyszczeń w gazie, które mówi, że gaz nie powinien zawierać żadnych składników na poziomie uniemożliwiającym jego transport, magazynowanie i/lub wykorzystanie bez dostosowania jakości gazu lub jego uzdatniania. Taki zapis jest mało precyzyjny, ale bez wątpienia w jego granicach może mieścić się limitowana zawartość pyłów w gazie ziemnym transportowanym sieciami gazowymi. Niestety na podstawie tak sformułowanego zapisu nie można jednoznacznie określić, jaka jest dopuszczalna zawartość pyłów w gazie, zgodnie z normą [25]. Wydaje się więc, że kwestię tę powinni rozstrzygnąć poszczególni operatorzy sieci w odniesieniu do uwarunkowań danej sieci. Jednak, jak pokazuje doświadczenie, w takich sytuacjach praktyka operatorów może być zróżnicowana. W przypadku Operatora Gazociągów Przesyłowych Gaz-System S.A. w Instrukcji Ruchu i Eksploatacji Sieci Przesyłowej znalazł się zapis, według którego zawartość pyłu w gazie wprowadzanym i transportowanym systemem przesyłowym nie może przekraczać $1 \mathrm{mg} / \mathrm{m}^{3}$ dla pyłów o średnicy cząstek powyżej $5 \mu \mathrm{m}$ [4]. Wymaganie to jest więc identyczne $\mathrm{z}$ wymaganiem zawartym w normie [14]. Inaczej jest w przypadku sieci dystrybucyjnej, dla której operator w Instrukcji Ruchu i Eksploatacji Sieci Dystrybucyjnej nie uwzględnił wymagania w zakresie dopuszczalnej zawartości pyłów w gazie transportowanym systemem dystrybucyjnym [3].

Oprócz gazu ziemnego istotnym paliwem gazowym jest biogaz. W Polsce jego wykorzystanie ogranicza się prawie wyłącznie do produkcji ciepła i/lub energii elektrycznej w miejscu wytworzenia biogazu [6], mimo iż od 2011 r. istnieją prawne możliwości zatłaczania biogazu rolniczego do sieci dystrybucyjnej gazu ziemnego. W przypadku biogazu wprowadzanego do sieci dystrybucyjnej gazowej jego jakość (podobnie jak jakość gazu ziemnego w sieciach dystrybucyjnych) została określona w odpowiednim rozporządzeniu. W tym przypadku jest to Rozporządzenie Ministra Gospodarki z dnia 24 sierpnia 2011 r. w sprawie szczegótowego zakresu obowiazku potwierdzania danych dotyczacych wytwarzanego biogazu rolniczego wprowadzonego do sieci dystrybucyjnej gazowej [29]. Wymagania jakościowe zawarte w tym dokumencie obejmują te same parametry, co wymienione w przywołanym wcześniej rozporządzeniu [28], czyli brak jest wymagań dotyczących maksymalnej zawartości pyłów w biogazie zatłaczanym do sieci. W zakresie parametrów jakościowych, jakimi powinien charakteryzować się biogaz wykorzystywany w celach energetycznych, 
transporcie czy zatłaczany do sieci, brak jest odpowiednich uregulowań technicznych zawartych np. w Polskich Normach (PN). Natomiast w zakresie prac Europejskiego Komitetu Normalizacyjnego, Komitetu Technicznego nr CEN/ TC 408 znajdują się dwa projekty norm europejskich z serii EN 16723, dotyczące jakości gazu ziemnego oraz biogazu wykorzystywanego w transporcie oraz zatłaczanego do sieci. Zgodnie z tymi projektami w przypadku biogazu zatłaczanego do sieci gazowej limitowana powinna być wartość takich parametrów jak [11]:

- zawartość wodoru, tlenu, tlenku węgla(IV), tlenku węgla(II), siarkowodoru, siarczku karbonylu, amoniaku oraz cyjanowodoru,

- zawartość par oleju,

- zawartość związków chloru i fluoru,

- zawartość węglowodorów aromatycznych jedno- i wielopierścieniowych,

- zawartość krzemu,

- punkt rosy wody i węglowodorów,

- zawartość pyłu.

Natomiast w przypadku biogazu wykorzystywanego jako paliwo transportowe zakres parametrów jakościowych, jakie są limitowane zgodnie z projektem normy, jest znacznie mniejszy i obejmuje takie parametry jak [12]:

- zawartość wodoru, siarkowodoru i siarczku karbonylu,

- zawartość par oleju,

- zawartość związków fluoru,

- zawartość krzemu,

- punkt rosy wody i węglowodorów,

- zawartość pyłu.

Dwa projekty norm $[11,12]$ przewidują zatem wprowadzenie limitów zawartości pyłów w biogazie, jednak autorom artykułu nie udało się dotrzeć do informacji, jakie limity dla zawartości pyłów w biogazie zostaną wprowadzone w opracowywanych normach.

Analiza dokumentów technicznych i prawnych w zakresie dopuszczalnej zawartości pyłów w biogazie pokazuje, że obecnie parametr ten nie jest limitowany. Jednak ze względu na to, że zawartość pyłów w paliwie może w istotny sposób wpływać na właściwości użytkowe paliwa, w przypadku biogazu spalanego w celu wytworzenia energii elektrycznej np. producenci silników łłokowych oceniają możliwość wykorzystania danego paliwa na podstawie opracowanych przez nich wytycznych. Zestawienie limitów dotyczących maksymalnej dopuszczalnej zawartości pyłów w biogazie dla silników tłokowych różnych producentów zestawiono w tablicy 1.

$\mathrm{Z}$ danych przedstawionych w tablicy 1 wynika, że producenci silników wymagają, aby spalany w nich biogaz zawierał nie więcej niż $10 \mathrm{mg}$ pyłu na $1 \mathrm{~m}^{3}$ metanu. Limity te są znacznie wyższe niż ograniczenia stawiane gazom ziem-
Tablica 1. Zestawienie wymagań w zakresie zawartości pyłów w biogazie według wybranych producentów silników [1]

\begin{tabular}{|c|c|c|}
\hline Producent & $\begin{array}{c}\text { Zawartość metanu } \\
{\left[\mathrm{mg} / \mathrm{m}^{3}\right]}\end{array}$ & $\begin{array}{c}\text { Maksymalna dopuszczalna } \\
\text { wielkość cząstek } \\
{[\mu \mathrm{m}]}\end{array}$ \\
\hline Jenbaher & $<50$ & $<3$ \\
\hline Deutz & $<10$ & $3 \div 10$ \\
\hline Catepillar & $<30$ & $<1$ \\
\hline Waukesha & \multicolumn{2}{|c|}{ Brak cząstek $>0,3 \mu \mathrm{m}$} \\
\hline
\end{tabular}

nym w sieciach gazowych zgodnie z normami $[14,15]$. Należy jednak zwrócić uwagę na fakt, że w przypadku producentów silników dodatkowym wymaganiem jest to, że gaz $\mathrm{z}$ reguły nie może zawierać cząstek pyłów większych niż $3 \mu \mathrm{m}$, a więc cząstek o dużo mniejszej średnicy niż średnica cząstek pyłów limitowana zgodnie z normami $[14,15]$. Analiza danych przedstawionych w tablicy 1 pokazała również duże zróżnicowanie wymagań poszczególnych producentów silników, zarówno w zakresie dopuszczalnej zawartości pyłów w biogazie, jak i maksymalnej dozwolonej wielkości cząstek. W wymaganiach producentów, z wyłączeniem Waukesha, brakuje również informacji, od jakiej minimalnej średnicy cząstek powinien być prowadzony pomiar zawartości pyłów, aby wynik mógł być w prawidłowy sposób odniesiony do stawianych wymagań. Podawane przez producentów silników wymagania w zakresie zawartości pyłów w biogazie świadczą o tym, że parametr ten powinien być limitowany, jeśli nie poprzez odpowiednie akty prawne, to przynajmniej jako wymaganie zawarte we właściwych standardach technicznych lub normach.

Szczególnym przykładem paliw gazowych są paliwa wykorzystywane w transporcie samochodowym, w tym głównie CNG. Wymagania jakościowe dla tego typu paliw określa Rozporządzenie Ministra Energii z dnia 30 czerwca 2016 r. w sprawie wymagań jakościowych dla sprężonego gazu ziemnego [27]. Zgodnie z tym dokumentem wymagania w zakresie zawartości pyłów w gazie są znacznie obniżone w stosunku do wcześniej obowiązującego Rozporządzenia Ministra Gospodarki z dnia 28 grudnia 2006 r. w sprawie wymagań jakościowych dla sprężonego gazu ziemnego (CNG) [30]. Zgodnie z zapisami zawartymi $\mathrm{w}$ rozporządzeniu [30] dopuszczalna zawartość pyłów w gazie wynosiła $1 \mathrm{mg} / \mathrm{m}^{3}$, natomiast obecnie dopuszczalna zawartość pyłów w gazie CNG wykorzystywanym w transporcie samochodowym jest 1000-krotnie większa i osiąga wartość aż $1 \mathrm{~g} / \mathrm{m}^{3}$. Zdaniem autorów brak jest istotnych przesłanek technicznych do wprowadzania tak ważnych zmian w wymaganiach stawianych CNG. Wymagania techniczne dla sprężonych gazów ziemnych wykorzystywanych jako paliwa samochodowe zawarte są również w przedmiotowych normach. W zakresie jakości 
sprężonego gazu ziemnego wykorzystywanego w transporcie Międzynarodowy Komitet Normalizacyjny ISO opracował dwa dokumenty: normę PN-EN ISO 15403-1 [26] oraz raport techniczny PKN-ISO/TR 15403-2 [13]. Dokumenty te dotyczą określania jakości gazu CNG stosowanego jako paliwo do pojazdów samochodowych oraz specyfikacji jakościowej tego typu paliwa. Wśród wielu parametrów, jakie powinny być kontrolowane i limitowane w gazie
CNG zgodnie z tymi dokumentami (takich jak: liczba metanowa, zawartość propanów i butanów, zawartość związków siarki oraz wilgoci), nie znalazły się jednak żadne wymagania w zakresie zawartości pyłów w gazie [13, 26]. Analizując powyższe informacje, można stwierdzić, że obecnie uregulowania prawne w zakresie zawartości pyłów w sprężonym gazie ziemnym $(\mathrm{CNG})$ stosowanym $\mathrm{w}$ transporcie nie są restrykcyjne.

\section{Analiza wymagań stawianych różnego typu gazom technicznym wykorzystywanym w przemyśle}

Skroplone i sprężone gazy techniczne, takie jak: azot, tlen, argon, hel oraz tlenek węgla(IV), mogą być na szeroką skalę wykorzystywane w różnych dziedzinach życia i gałęziach przemysłu. Zasilają one między innymi urządzenia kontrolno-pomiarowe (np. analizatory gazów pracujące w trybie on-line) oraz urządzenia tnące. Są również wykorzystywane do chłodzenia urządzeń oraz zapewnienia procesom technologicznym atmosfery utleniającej, redukującej lub obojętnej. Stąd też jakość tych gazów powinna być kontrolowana i ściśle określona. Wymagania dotyczące jakości poszczególnych gazów technicznych sprężonych lub skroplonych, stosowanych w przemyśle, zebrano w przedmiotowych normach. Zgodnie z zapisami odpowiednich norm gazy techniczne podzielono na gatunki w zależności od zawartości składnika głównego w danym gazie. Zgodnie $\mathrm{z}$ tym podziałem gazy techniczne o najniższej czystości oznaczono symbolem N20 - są to gazy zawierające minimum 99,0\% składnika głównego. Natomiast gatunek gazu o najwyższej czystości oznaczono symbolem N60. Zawartość składnika głównego w gazie należącym do gatunku N60 wynosi minimum 99,9999\% [18-24]. Liczba możliwych gatunków gazów w obrębie jednego gazu technicznego jest różna i może wynosić od 2 - dla wodoru sprężonego, do 6 gatunków - dla argonu i azotu sprężonego oraz argonu i tlenku węgla(IV) skroplonego [18-24]. Wszystkie wymienione normy [18-24] dopuszczają stosowanie innych gatunków gazów technicznych, jeżeli ich jakość zostanie uzgodniona w porozumieniu między dostawcą a odbiorcą. W zależności od rodzaju gazu technicznego przedmiotowe normy określają dopuszczalne zawartości różnego typu zanieczyszczeń w gazach. Rodzaje zanieczyszczeń limitowane w poszczególnych gazach technicznych zebrano w tablicy 2 .

Spośród wielu zanieczyszczeń limitowanych w gazach technicznych wymagania zawarte w normach [18-24] nie limitują zawartości pyłów dla żadnego rodzaju gazu. Biorąc jednak pod uwagę minimalne ilości głównego składnika w gazach należących do różnych gatunków, można stwierdzić, że maksymalna zawartość pyłów w gazach technicznych nie może przekraczać $0,0001 \%$ dla gazów z gatunku N60 oraz 1\% dla gazów z gatunku N20. Uwzględniając natomiast gęstości poszczególnych gazów [5], wyliczyć można, że dla gazu o najmniejszej gęstości (wodór) zawartość pylów nie powinna przekraczać $0,082 \mathrm{mg} / \mathrm{m}^{3}$ (dla wodoru N60) oraz $820 \mathrm{mg} / \mathrm{m}^{3}$ (dla wodoru N20). Natomiast dla gazu o największej gęstości (tlenku węgla(IV)) limity te będą wynosić odpowiednio: $1,847 \mathrm{mg} / \mathrm{m}^{3}$ dla gazu $\mathrm{N} 60$ oraz $18,47 \mathrm{~g} / \mathrm{m}^{3}$ dla gazu N20. Oczywiście będą one prawdziwe jedynie w sytuacji, gdy analizowany gaz nie będzie zawierał poza pyłami żadnych innych zanieczyszczeń, np. w postaci wilgoci czy obecności innych składników gazowych. Dodatkowo takie pośrednie wyrażenie dopuszczalnej zawartości pyłów w postaci $\%(v / v)$ jest trudne $w$ interpretacji, gdyż wyniki analiz zawartości pyłów w gazach wyrażane są najczęściej w $\mathrm{mg} / \mathrm{m}^{3}$. W celu prawidłowego zinterpretowania otrzymanego wyniku niezbędne jest wykonanie dodatkowych analiz w zakresie obecności innych możliwych zanieczyszczeń występujących w gazie, a także gęstości badanego medium.

Tablica 2. Zanieczyszczenia limitowane w gazach technicznych wykorzystywanych do celów technicznych [18-24]

\begin{tabular}{|l|c|c|c|c|c|c|c|c|c|c|c|c|}
\hline \multicolumn{1}{|c|}{ Rodzaj zanieczyszczenia } & $\mathrm{O}_{2}$ & $\mathrm{~N}_{2}$ & $\mathrm{CO}$ & $\mathrm{CO}_{2}$ & $\mathrm{H}_{2}$ & $\mathrm{Ne}$ & $\mathrm{CH}_{4}$ & $\mathrm{C}_{\mathrm{n}} \mathrm{H}_{\mathrm{m}}$ & $\mathrm{H}_{2} \mathrm{O}$ & $\mathrm{Cl}$ & $\mathrm{H}_{2} \mathrm{~S}$ & $\mathrm{Alkalia}$ \\
\hline Wodór sprężony & TAK & NIE & NIE & NIE & NIE & NIE & NIE & NIE & TAK & TAK & TAK & TAK \\
\hline $\begin{array}{l}\text { Tlenek węgla(IV) skroplony } \\
\text { i zestalony }\end{array}$ & TAK & TAK & TAK & NIE & TAK & NIE & NIE & TAK & TAK & NIE & NIE & NIE \\
\hline Tlen sprężony i skroplony & NIE & TAK & NIE & NIE & NIE & NIE & NIE & NIE & TAK & NIE & NIE & NIE \\
\hline Azot sprężony i skroplony & TAK & NIE & TAK & TAK & NIE & NIE & TAK & NIE & TAK & NIE & NIE & NIE \\
\hline Argon sprężony i skroplony & TAK & TAK & TAK & TAK & TAK & NIE & TAK & NIE & TAK & NIE & NIE & NIE \\
\hline Hel sprężony i skroplony & TAK & TAK & TAK & TAK & TAK & TAK & TAK & NIE & TAK & NIE & NIE & NIE \\
\hline
\end{tabular}




\section{Podsumowanie}

W chwili obecnej w prawodawstwie polskim z reguły brak jest odpowiednich uregulowań prawnych dotyczących dopuszczalnych zawartości pyłów w paliwach gazowych oraz gazach technicznych. Tego typu uregulowania odnoszą się wyłącznie do gazu CNG stosowanego do napędu pojazdów samochodowych, jednak zdaniem autorów są one mało restrykcyjne [27].

W zakresie jakości paliw gazowych można znaleźć natomiast uregulowania techniczne zawarte w odpowiednich normach polskich i europejskich, uwzględniające zawartość pyłów w gazie. Niemniej jednak parametr ten w sposób jednoznaczny limitowany jest wyłącznie w gazach ziemnych transportowanych sieciami gazowymi. W tym przypadku zapisy norm PN-C-04752:2011 [14] i PN-C-04753:2011 [15] określają w sposób oczywisty, że dopuszczalna zawartość pyłów w gazie nie może przekraczać $1 \mathrm{mg} / \mathrm{m}^{3}$ dla pyłów o średnicy cząstek powyżej $5 \mu \mathrm{m}$. Należy jednak pamiętać, że normy te mogą zostać niedługo wycofane z krajowego zbioru norm ze względu na sprzeczne zapisy w porównaniu z normą PN-EN 16726:2016 [25]. Dodatkowo wprowadzona niedawno norma [25] dotycząca jakości gazu ziemnego nie limituje bezpośrednio zawartości pyłów w gazie, podaje jedynie informację, że gaz nie powinien posiadać żadnych składników w ilościach, które mogłyby przeszkadzać w jego transporcie. W niedalekiej przyszłości można spodziewać się również, że w przypadku biogazu wprowadzanego do sieci oraz biogazu wykorzystywanego w transporcie opracowywane normy będą zawierały zapisy ograniczające zawartość pyłów w biogazie. Takich zapisów nie wprowadzono jednak w raporcie technicznym [13] dotyczącym jakości sprężonego gazu ziemnego stosowanego jako paliwo do pojazdów, co dowodzi, że podejście do kwestii limitowania zawartości pyłów w paliwach gazowych jest zróżnicowane. Również w przypadku gazów technicznych brakuje jednoznacznych wymagań dotyczących zawartości pyłów w tych gazach. Limity te można odnieść jedynie do minimalnej zawartości składnika głównego [18-24].

Przeprowadzona analiza uwarunkowań technicznych wyraźnie pokazuje, że zapisy poszczególnych norm dotyczące oznaczania zawartości pyłów w gazach są mocno zróżnicowane oraz że normalizacja w zakresie jakości gazów ulega $\mathrm{w}$ chwili obecnej dynamicznym zmianom. Taka sytuacja jest niekorzystna z punktu widzenia prowadzenia kontroli jakości gazu czy opracowywania lub wdrażania nowych metodyk badawczych w zakresie zawartości pyłów, gdyż trudno jest przewidzieć, jakimi parametrami będzie musiała charakteryzować się metoda pomiarowa, by sprostać zapisom nowo powstających norm.

Prosimy cytować jako: Nafta-Gaz 2017, nr 7, s. 496-501, DOI: 10.18668/NG.2017.07.07

Artykuł nadesłano do Redakcji 8.12.2016 r. Zatwierdzono do druku 20.05.2017 r.

Artykuł powstał na podstawie pracy statutowej pt.: Analiza zawartości pyłów w gazie jako element kontroli jakości gazu - praca INiG - PIB na zlecenie MNiSW; nr zlecenia: 104/GE/16, nr archiwalny: DK-4100-104/16.

\section{Literatura}

[1] Dudek J., Klimek P., Kołodziejak G., Niemczewska J., Zalewska-Bartosz J.: Technologie energetycznego wykorzystania gazu składowiskowego. Prace Naukowe Instytutu Nafty i Gazu nr 174, 2010, s. 44.

[2] Holewa J., Szlęk M.: Ocena jakości gazów palnych. Nafta-Gaz 2013, nr 6, s. 450-454

[3] Instrukcja Ruchu i Eksploatacji Sieci Dystrybucyjnej. Polska Spółka Gazownictwa Sp. z o.o., Warszawa, lipiec 2016.

[4] Instrukcja Ruchu i Eksploatacji Sieci Przesyłowej. Wersja 025. Operator Gazociągów Przesyłowych Gaz-System S.A., Warszawa, luty 2016.

[5] Lide D.R. (red.): CRC Handbook of Chemistry and Physics. Wyd. 90. Boca Raton: CRC Press 2009, s. 4-66.

[6] Niemczewska J.: Characteristics of utilization of biogas technology. Nafta-Gaz 2012, nr 5, s. 293-297.

[7] Rachwalski J., Iwasyk Z., Demczak M., Steczko K.: Jakość gazu ziemnego w polskim systemie gazowniczym. Nafta-Gaz 1999, nr 9, s. 533-546.

[8] Schuster T.: Analiza możliwości wykorzystania wyników systemu monitoringu jakości gazu do weryfikacji obszarów rozli- czeniowych ciepła spalania. Nafta-Gaz 2016, $\mathrm{nr} 7$, s. 551-557, DOI: 10.18668/NG.2016.07.09.

[9] Schuster T., Bogucki A.: Monitoring parametrów cieplnych gazu ziemnego $w$ systemach dystrybucyjnych $w$ kontekście rozliczeń energetycznych. Nafta-Gaz 2012, nr 9, s. 623-630.

[10] Szlęk M., Holewa J.: Optymalizacja metody oznaczania zawartości związów siarki występujacych w paliwach gazowych. Nafta-Gaz 2015, nr 5, s. 308-313.

\section{Akty prawne i normatywne}

[11] Draft prEN 16723-1 Natural gas and biomethane for use in transport and biomethane for injection in the natural gas network-Part 1: Specifications for biomethane for injection in the natural gas network; marzec 2014.

[12] Draft prEN 16723-2 Natural gas and biomethane for use in transport and biomethane for injection in the natural gas network-Part 2: Automotive fuel specifications; marzec 2014.

[13] PKN-ISO/TR 15403-2:2010 Gaz ziemny - Gaz ziemny stosowany jako sprężone paliwo do pojazdów - Cześć 1: Specyfikacja dotyczaca jakości. 
[14] PN-C-04752:2011 Gaz ziemny - Jakość gazu w sieci przesytowej.

[15] PN-C-04753:2011 Gaz ziemny - Jakość gazu dostarczanego odbiorcom z sieci dystrybucyjnej.

[16] PN-C-84908:1997 Gazy techniczne - Wodór sprężony.

[17] PN-C-84909:1997 Gazy techniczne - Dwutlenek węla skroplony, skroplony schtodzony i zestalony.

[18] PN-C-84910:1997 Gazy techniczne - Tlen sprężony.

[19] PN-C-84911:1997 Gazy techniczne - Azot skroplony.

[20] PN-C-84911:1997 Gazy techniczne - Tlen skroplony.

[21] PN-C-84912:1997 Gazy techniczne - Azot sprężony.

[22] PN-C-84920:1997 Gazy techniczne - Argon sprężony.

[23] PN-C-84921:1997 Gazy techniczne - Argon skroplony.

[24] PN-C-84922:1997 Gazy techniczne - Hel sprężony i skroplony.

[25] PN-EN 16726:2016 Infrastruktura gazowa - Jakość gazuGrupa $H$

[26] PN-EN ISO 15403-1:2010 Gaz ziemny - Gaz ziemny stoso-

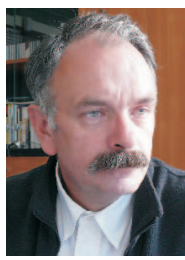

Mgr inż. Tadeusz SCHUSTER

Główny specjalista inżynieryjno-techniczny

w Zakładzie Ochrony Środowiska.

Instytut Nafty i Gazu - Państwowy Instytut Badawczy

ul. Lubicz 25 A

31-503 Kraków

E-mail: tadeusz.schuster@inig.pl wany jako sprężone paliwo do pojazdów - Cześć 1: Określanie jakości.

[27] Rozporzadzenie Ministra Energii z dnia 30 czerwca 2016 r. w sprawie wymagań jakościowych dla sprężonego gazu ziemnego (CNG) (Dz.U. z 2016 r., poz. 1094).

[28] Rozporzadzenie Ministra Gospodarki z dnia 2 lipca $2010 \mathrm{r}$. $w$ sprawie szczegółowych warunków funkcjonowania systemu gazowego (Dz.U. z 2010 r. nr 133, poz. 891, wraz z późn. zm.).

[29] Rozporządzenie Ministra Gospodarki z dnia 24 sierpnia 2011 r. w sprawie szczegółowego zakresu obowiąku potwierdzania danych dotyczacych wytwarzanego biogazu rolniczego wprowadzonego do sieci dystrybucyjnej gazowej (Dz.U. z 2011 r. nr 187, poz. 1117).

[30] Rozporzadzenie Ministra Gospodarki z dnia 28 grudnia 2006 r. w sprawie wymagań jakościowych dla sprężonego gazu ziemnego (CNG) (Dz.U. z 2006 r. nr 251, poz. 1850). Uchylone $\mathrm{w}$ dniu 15.04.2016 r.

Mgr Jadwiga HOLEWA-RATAJ

Starszy specjalista badawczo-techniczny w Zakładzie Ochrony Środowiska.

Instytut Nafty i Gazu - Państwowy Instytut Badawczy

ul. Lubicz 25 A

31-503 Kraków

E-mail: jadwiga.holewa@inig.pl

\section{OFERTA}

\section{ZAKŁAD OCHRONY ŚRODOWISKA}

Zakres działania:

- $\quad$ analiza zagrożeń środowiska, związanych z działalnością przemysłu naftowego i gazowniczego,

- opracowanie i weryfikacja technologii środowiskowych w przemyśle nafty i gazu,

- monitoring i badania laboratoryjne jakości środowiska (powietrza, wód i gleby) na terenach poszukiwania i eksploatacji złóż węglowodorów i innych terenach przemysłowych,

- badania laboratoryjne ścieków (w tym wód złożowych i cieczy technologicznych) i odpadów (w tym odpadów wiertniczych, odpadów po zabiegu hydraulicznego szczelinowania) oraz ocena ich potencjalnej szkodliwości dla środowiska,

- $\quad$ klasyfikacja odpadów wydobywczych wraz ze sporządzaniem podstawowej charakterystyki odpadu,

- $\quad$ analiza zawartości rtęci w próbkach środowiskowych (stałych i ciekłych), mieszaninach gazowych i materiałach przemysłowych,

- $\quad$ inwentaryzacja emisji metanu z sektora poszukiwania, wydobycia, magazynowania oraz przesyłu i dystrybucji gazu,

- ocena wielkości emisji gazów cieplarnianych,

- $\quad$ ocena jakości paliw węglowodorowych: gazu ziemnego, koksowniczego, gazów wytwarzanych w przemyśle, biogazu,

- $\quad$ kompleksowa analiza biogazu, w tym analiza związków krzemu, chloru i fluoru,

- $\quad$ monitoring jakości gazu ziemnego w systemie gazowniczym,

- badania podkładów kolejowych odpadowych, wykorzystywane do ich klasyfikacji pod względem bezpieczeństwa dla środowiska,

- $\quad$ sporządzanie oraz aktualizacja kart charakterystyki substancji i mieszanin niebezpiecznych, zgodnie z obowiązującym prawodawstwem,

- $\quad$ pobór próbek wód, ścieków, gleb, odpadów oraz gazu ziemnego, biogazu i innego typu mieszanin gazowych.

Kierownik: dr Ewa Kukulska-Zając

Adres: ul. Bagrowa 1, 30-733 Kraków

Telefon: 12617743

Faks: 126531665

E-mail: ewa.kukulska@inig.pl 